\title{
THE INFLUENCE OF WELDED JOINT QUALITY ON SAFETY AND RELIABILITY IN OPERATION
}

\author{
Otakar Bokůvka ${ }^{1 *}$, Tatiana Liptáková ${ }^{1}$, Peter Palček ${ }^{1}$, Mária Chalupová1 ${ }^{1}$ Libor \\ Trško ${ }^{1}$ \\ ${ }^{1}$ Department of Materials Engineering, Faculty of Mechanical Engineering, University of Žilina, Univerzitná 1, \\ 01026 Žilina, Slovak Republic \\ * corresponding author: Tel.: +421 41513 5140, e-mail: otakar.bokuvka@fstroj.uniza.sk
}

\begin{abstract}
Resume
The quality of welded joint is an assumption of long-term reliability in operation. On the contrary, defective work of bad quality welded joint leads to fracture and crashes of plants. In this paper the authors state that experimentally obtained causes of rails and pipes fractures were the result of bad realization of welded joint. Pores, blowholes, slags, lack of fusion, non-plastic non-metallic particles, cracks, shrink holes were the defects observed in the welded joint area. These defects substantially decreased the load-bearing cross section and the final result was fracture. The railway and high-pressure gas lines out of operation are undesirable and accompanied by considerable financial losses.
\end{abstract}

Available online on April 2013: http://www.qpij.pl/

\author{
Article info \\ Article history: \\ Received 10 June 2013 \\ Accepted 02 September 2013 \\ Keywords: \\ rails, \\ pipes, \\ welded joint, \\ defects, \\ fractures, \\ causes \\ ISSN 2353-5156
}

\section{Introduction}

Useful properties, quality of components and construction are subject to chemical composition, microstructure, properties of used material and the technologies used for their manufacturing. Then, the system of their interaction is entered by economic parameters, mainly the costs of used material and technologies and it is important to point out the influence of the mentioned factors on the environment (PTÁČEK L. 1999, BORKOWSKI S. 2007, BORKOWSKI S. 2008, BORKOWSKI S. 2011).

Welding is the most economical way to non-rewirable joint metals and their alloys. It is the only way of connecting two or more components to one, non-rewirable corpus. The purpose of welding is to create a permanent joint, which has required properties. Usually, it is toughness, ductility, resistance to degradation processes, which can course during the whole time of the joint use, and resistance to sudden failure, which means safety, usually evaluated by fracture toughness and integrity of weld joint
(HRIVŇÁK I. 2009, TURŇA M. 1989, MEŠKO J. 1999, SLÁDEK A. 2000).

The division and characteristic of individual methods of welding is mentioned in Hrivň́k I. 2009. A separate group of welding methods is aluminothermic welding used for welding of rails. $H$. Goldschmidt laid the foundations of aluminothermic welding in 1899. The technical meaning was in the reaction of aluminothermic mixture where the reduction of ferrous oxides by aluminium occurs, which creates a highly overheated melted metal with a big thermal content. The melted metal is used as a source of heat and filler material for welded joint.

Aluminothermic mixture contains oxides of metals, aluminium and alloying elements. The temperature of ignition of this mixture is $800 \div 1100^{\circ} \mathrm{C}$ (special matches are used). The reaction of aluminothermic mixture lasts for a few seconds, while about $50 \%$ of the steel is deoxidated and about $50 \%$ is slag. Deoxidated welding metal is heated at the temperature of about $2100 \div 2200^{\circ} \mathrm{C}$ while exothermic 
reaction is created. As a result of this reaction overheated metal and liquid slag are created.

Out of $1 \mathrm{~kg}$ of aluminothermic mixture is obtained about $477 \mathrm{~g}$ of slag, $533 \mathrm{~g} \mathrm{Fe}$ and $3353.04 \mathrm{~kJ}$ of heat. Optimal aluminothermic mixture contains $24.5 \% \mathrm{Al}$ and $75.5 \%$ of ferrous oxides. In terms of thermal effect, the best oxide for this reaction contains $86 \% \mathrm{Fe}_{2} \mathrm{O}_{3}$ and $14 \% \mathrm{FeO}$.

Depending on the type of Fe oxides (FeO, $\mathrm{Fe}_{2} \mathrm{O}_{3}, \mathrm{Fe}_{3} \mathrm{O}_{4}$ ), the deoxidation with $\mathrm{Al}$ occurs according to these relations:

$$
\begin{aligned}
& 3 \mathrm{FeO}+2 \mathrm{Al}=\mathrm{Al}_{2} \mathrm{O}_{3}+3 \mathrm{Fe} \\
& \mathrm{Fe}_{2} \mathrm{O}_{3}+2 \mathrm{Al}=\mathrm{Al}_{2} \mathrm{O}_{3}+2 \mathrm{Fe} \\
& 3 \mathrm{Fe}_{2} \mathrm{O}_{3}+8 \mathrm{Al}=4 \mathrm{Al}_{2} \mathrm{O}_{3}+9 \mathrm{Fe}
\end{aligned}
$$

The welding process is similar to casting welding (HRIVŇÁK I. 2009, RAILTECH INTERNATIONAL 1993 and 1994, SCHRUEDER L. C. 1984, SLÁDEK A. 2000, TURŇA M. 1989).

In engineering practice fractures sometimes occur near the welded joint during the operation of components and constructions caused by using wrong welding parameters. Failures of components and constructions occur accompanied by economic losses (BOKUீVKA O. 2000, LIPTÁKOVÁ T. 1997).

In this paper the authors provide experimentally obtained causes of rails and pipes fractures resulting from bad realization of welded joint.

\section{Experimental investigation of fracture causes}

The rails and pipes were damaged (fractures) in operation in the area of weld joint, see Figure 1 and Figure 2.

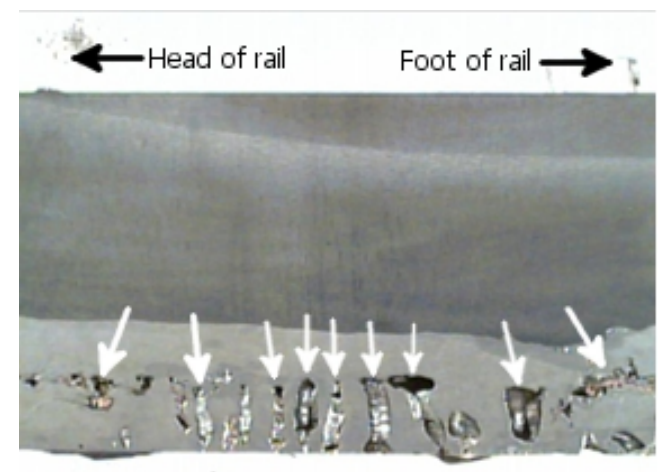

Fig. 1. Rail weld joint fracture, arrowhead notation - defects

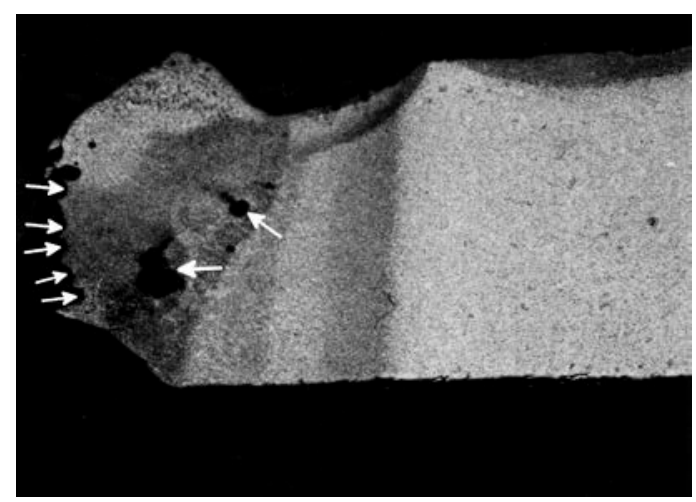

Fig. 2. Pipe weld joint fracture arrowhead notation - defects

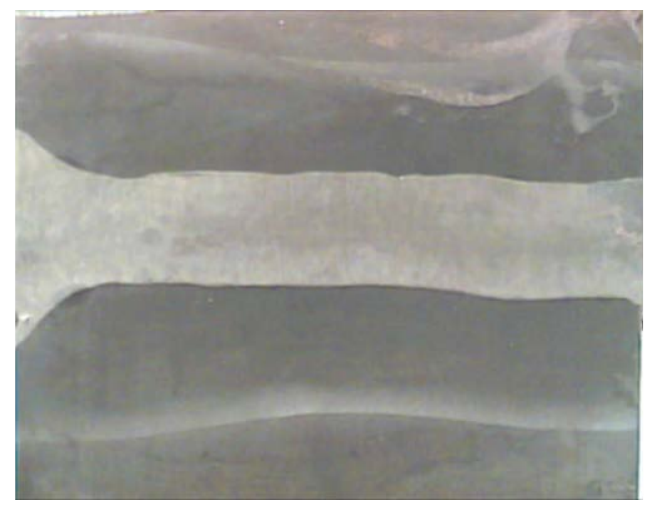

Fig. 3. Rail weld joint, outside of damage

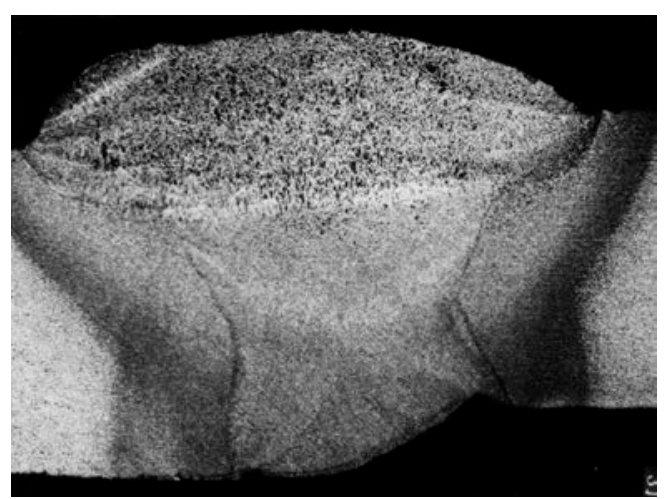

Fig. 4. Pipe weld joint, outside of damage

For the verification of basic material properties, including fracture causes, the selected experimental methods of physical metallurgy and threshold state of materials were used (SKOČOVSKÝ P. 2006, BOKŮVKA O. 2002, LEITNER B. 2003). The results of quantitative chemical analysis (Table 1 and Table 2), metallography and electron microscopy analysis (Figure 5 and Figure 6), tensile and hardness tests confirmed that the used structural material, structural steels correspond with the material used as rail steels (Table 1) resp. pipes of high- 
pressure gas lines (Table 2). The chemical composition and tensile strength are comparable, the microstructure is pearlite ferrite with a very small portion of ferrite (Figure 5, rail steel) resp. ferrite and perlite with non-uniform polyedric grains (Figure 6, pipe steel). In the case of pipe steel there was a higher value of sulphur observed, which deteriorates the welding property of the material. (SKOČOVSKÝ P. 2000, SKOČOVSKÝ P. 2006).

The metallography analysis (Figure 2, Figure 7, Figure 8, pipe and Figure 1, rail) electron microscopy (Figure 9, Figure 10, rail) and radiography testing demonstrated considerable occurrence of pores, blowholes, slags, lack of fusion, non - plastics non metallic particles, cracks, shrink holes, weld reinforcement, unfused root, irregular surface, spatter, defects in root and so on.

Table 1. Rail, chemical composition (in weight \%) and tensile strength $R_{m}(\mathrm{MPa})$

\begin{tabular}{l|cccccc}
\hline Rails & $\mathbf{C}$ & $\mathbf{M n}$ & $\mathbf{S i}$ & $\mathbf{P}$ & $\mathbf{S}$ & $\mathbf{R}_{\mathbf{m}}$ \\
\hline verification & 0.686 & 1.01 & 0.36 & 0.014 & 0.012 & 1080 \\
material & 0.55 & 0.75 & 0.15 & max. & max. & min. \\
standard & 0.80 & 1.40 & 0.50 & 0.050 & 0.050 & 950 \\
\hline
\end{tabular}

Table 2. Pipe, chemical composition (in weight \%) and mechanical properties ( $R_{m}(M P a), A 5(\%)$ )

\begin{tabular}{l|cccccccccc}
\hline Pipe & $\mathbf{C}$ & $\mathbf{M n}$ & $\mathbf{S i}$ & $\mathbf{P}$ & $\mathbf{S}$ & $\mathbf{C u}$ & $\mathbf{N i}$ & $\mathbf{C r}$ & $\mathbf{R}_{\mathbf{m}}$ & A5 \\
\hline verification & 0.17 & 1.12 & 0.28 & 0.033 & 0.058 & 0.205 & 0.12 & 0.125 & 536.1 & 20.8 \\
& & & & & & & & & & \\
material & 0.16 & 1.00 & 0.15 & max. & max. & max. & max. & max. & 460 & 21.0 \\
standard & 0.22 & 1.40 & 0.40 & 0.04 & 0.04 & 0.30 & 0.30 & 0.30 & 550 & \\
\hline
\end{tabular}

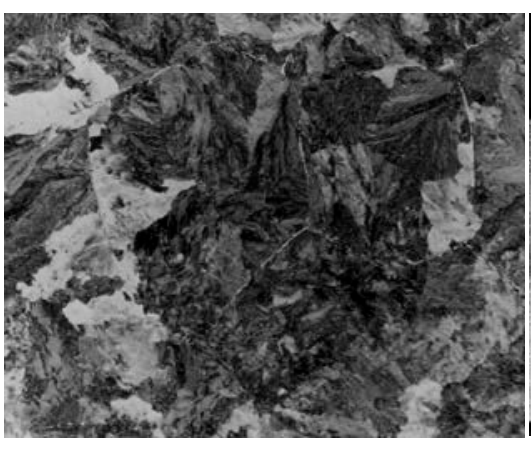

Fig. 5. Rail microstructure, mag. 500x, etch $3 \%$ Nital

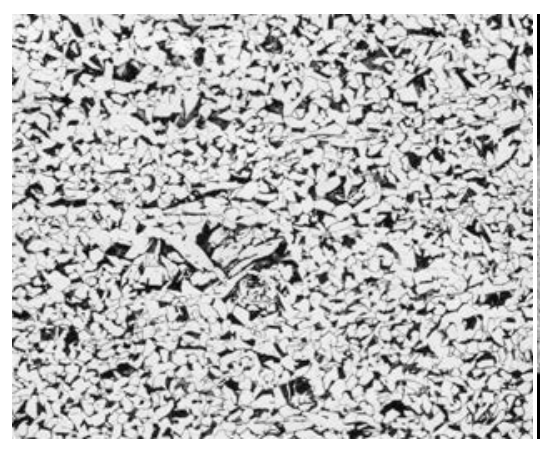

Fig. 6. Pipe microstructure, mag. $100 x$, etch $1 \%$ Nital

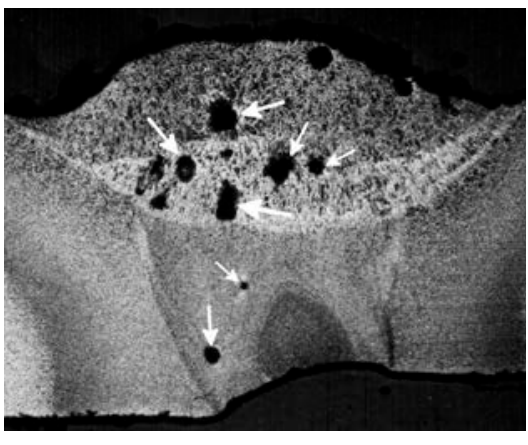

Fig. 7. Pipe, arrowhead notation pores, mag. $6.3 x$, etch $1 \%$ Nital

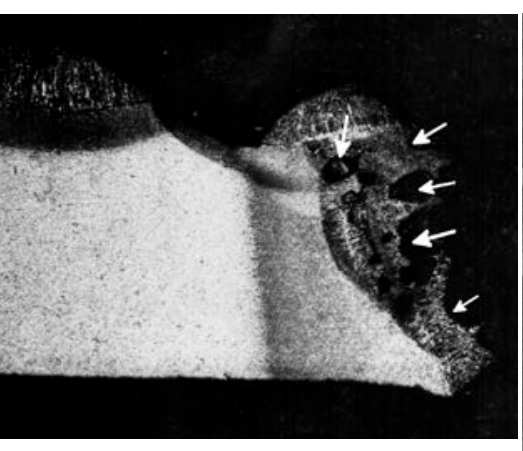

Fig. 8. Pipe, fracture, arrowhead notation - defects, pores, mag. $6.3 x$, etch $1 \%$ Nital

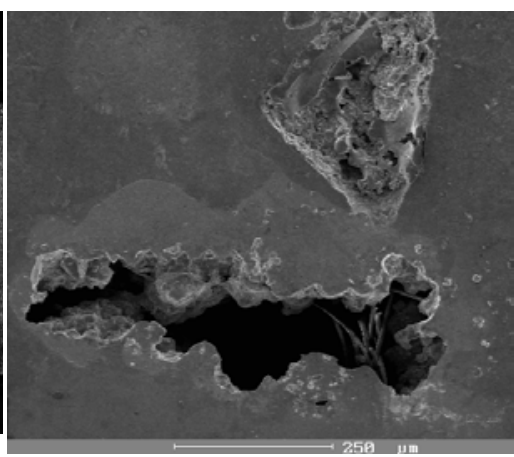

Fig. 9. Rail, shrink hole, SEM, etch $3 \%$ Nital

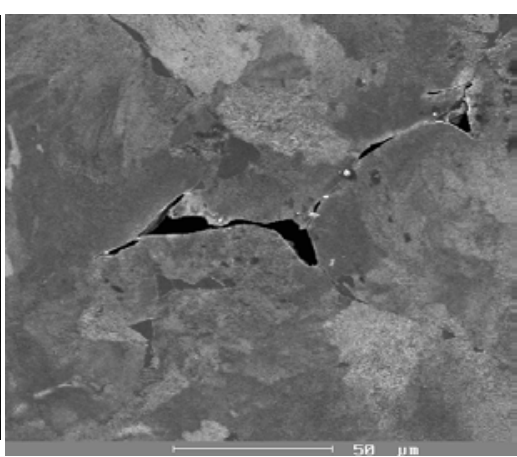

Fig. 10. Rail, cracks, SEM, etch $3 \%$ Nital 
The size and amount of defects in the rail increased in direction from the head of the rail to the foot of the rail (in the direction of the highest bending, loading), Figure 1, the defects covering a constituent part of the weld area, Figure 1, Figure 2 and Figure 8. As an opposite of the above, the weld of rail (Figure 3) and weld of pipe (Figure 4) beyond the area of fracture are shown. Very important is the fact, that the pipes of high - pressure gas lines and rails of railway lines are loaded not only statically but also dynamically (BOKŮVKA O. 2002, SKOČOVSKÝ P. 2006). These defects serve as initiation points for the start of the degradation mechanism, they have substantially decreased the load - bearing cross section. With regard to these facts, the final results are fractures and the railway and high - pressure gas lines are interrupted (SKOČOVSKÝ P. 2000, SKOČOVSKÝ P. 2006).

\section{Conclusions}

The quality of weld joint is determined by using exact welding rules prescribed by technological descriptions. The preparation of the welding place (for example, cleaning, grease removing with the aim to remove all kinds of dirt including corrosion products, drying out, heating before welding, etc.), weld manufacturing (human factor) and ex-post control of the weld (visual and with the use of defectoscopy methods) are the assumption factors of high quality weld joint. Breaking these rules leads to defects in the weld joint and, subsequently, to failure of components and constructions, which causes considerable economic losses. The observance of optimal rules in the chain chemical composition, microstructure and technology leads to high use properties, required quality of components and constructions.

\section{Acknowledgements}

The research was supported partially by Scientific Grant Agency of the Ministry of Education,
Science and Sport of Slovak Republic and Slovak Academy of Science, grant No. 1/0743/12.

\section{References}

[1] BoRKOWSKI S., TILlOVÁ E. 2007. Improvement of Quality Regarding Processes and Materials. Warszawa.

[2] BoRKowsKi S., PALČEK P. 2008. Quality of Materials and Products. Saint - Petersburg.

[3] Borkowski S., Ulewicz R. 2011. Toyotarity. Heijunka. Dnepropetrovsk.

[4] BoKU゚VKa O. et al. 2000. Posúdenie príčin lomov kol'ajníc. Report No. 80/2000. KMI, ŽU Žilina.

[5] BokU゚VKa O., Nicoletto G., KunZ L., PALČEK P., Chalupová M. 2002. Low and High Frequency Fatigue Testing. EDIS ŽU Žilina.

[6] HRIVŇÁK I. 2009. Zváranie a zvaritel'nost' materiálov, STU Bratislava.

[7] LEITNER B. et al. 2003. Nedeštruktívne skúšanie materiálov v plynárenstve. EDIS ŽU Žilina.

[8] LiptákovÁ T. et al. 1997. Posúdenie príčin porušenia potrubia vysokotlakého plynovodu. Report No. 34/1997, KMI, ŽU Žilina.

[9] MeŠKO J., VESELKO J. 1999. Zváranie a opravy grafitických liatin. EDIS ŽU Žilina.

[10] PTÁČEK L. et al. 1999. Nauka o materiálu II. CERM, s. r. o. Brno.

[11] RAILTECH INTERNATIONAL. 1993. Technologický postup aluminotermického svařování kolejnic, příručka 325.

[12] RAILTECH INTERNATIONAL. 1994. Technologický postup aluminotermického svařování kolejnic, př́ručka 121.

[13] Schrueder L. C., PoIRIER D. R. 1984. The Mechanical Properties of Termite Welds in Premium Alloy Rails. Mat. Science and Engineering, 63, p. $23-33$.

[14] SkOČOvskÝ P., BOKƯVKA O., KONEČNÁ R., TILlOVÁ E. 2006. Náuka o materiáli pre odbory strojnícke. EDIS ŽU Žilina.

[15] SKOČOvSKÝ P., PALČEK P., KONEČNÁ R., VÁRKOLY L. 2000. Konštrukčné materiály. EDIS ŽU Žilina.

[16] SlÁdeK A., MeŠKo J., DonIČ T. 2000. Beztrieskové technológie I. EDIS ŽU Žilina.

[17] TURŇA M. 1989. Špeciálne metódy zvárania. Alfa Bratislava. 